\title{
IMMUNIZACJA JAKO \\ PARADYGMAT NOWOCZESNOŚCI
}

\section{Z ROBERTEM ESPOSITEM ROZMAWIA TIMOTHY CAMPBELL ${ }^{1}$}

Timothy Campbell: Biopolityka jest we współczesnej filozofii włoskiej szeroko dyskutowanym tematem, co widać zwłaszcza w pracach Giorgia Agambena, Antonia Negriego i Twoich. Czym wytłumaczyłbyś to zainteresowanie i co odróżnia wasze podejścia?

Roberto Esposito: To prawda, że włoscy myśliciele, obok Àgnes Heller i Donny Haraway, wnieśli chyba największy i najbardziej oryginalny wkład w rozwój tematyki biopolitycznej, podejmowanej w latach 70. przez Michela Foucaulta. Jednym z powodów może być specyficzny, graniczny status Włoch, które geograficznie i kulturowo oddzielają Europę (Północ) od świata śródziemnomorskiego (Południe). To społeczne i kulturowe pęknięcie jest źródłem doskwierających nam podziałów, ale bywa też atutem: poczucie przechodniości uwrażliwia chociażby na biopolitykę, która przecież także sytuuje się na przecięciu pozornie nieprzystających języków polityki i życia, antropologii i prawa.

Inną przyczynę widzę w specyfice włoskiej tradycji filozoficznej, gdzie polityczność zawsze odgrywała znaczącą rolę. Ograniczając się tylko do autorów powszechnie znanych, jak Niccolò Machiavelli, Giambattista Vico, Benedetto Croce czy Antonio Gramsci, można zauważyć, że ich myśl ogniskuje się tam, gdzie polityka spotyka historię. Zwłaszcza Vico i Gramsci uczynili z przecięcia polityki i historii punkt, z którego ciągle i obowiązkowo bierze początek namysł filozoficzny we Włoszech. Polityczna interpretacja teraźniejszości, to, co Foucault nazywał „ontologią aktualności”, wyróżnia włoską filozofię na tle anglosaskiej tradycji analitycznej, niemieckiej hermeneutyki czy francuskiej dekonstrukcji.

Równie wyrazistym horyzontem zainteresowania włoskiej filozofii była i jest problematyka życia. Sposób, w jaki ujmowali ją tacy autorzy, jak Giordano Bruno i Tommaso Campanella, antycypował poniekąd filozofię Barucha Spinozy, która odwróciła mechanicystyczny, antynaturalistyczny wektor nowożytnej filozofii, zapoczątkowanej przez Kartezjusza i Thomasa Hobbesa. To w opozycji do tej dwójki rozwinęła się filozofia

Przekład z języka angielskiego dokonany na podstawie: R. Esposito, T. Campbell, Interview, trans. by A. Paparcone, „Diacritics” 2006, Vol. 36, nr 2, s. 49-56. Dziękujemy Timothy’emu Campbellowi za zgodę na publikację. Tytuł nadany przez redakcję (wszystkie przypisy pochodzą od redakcji). 
drugiego Odrodzenia włoskiego, zmierzająca w kierunku pogodzenia historii z naturą, a życia ludzkiego z życiem świata. Ta odrębność od głównego nurtu filozofii nowożytnej jest zapewne kolejnym, trzecim już czynnikiem decydującym o dzisiejszej popularności tematyki biopolitycznej we Włoszech.

Jeśli natomiast pytasz, jak się ma moje ujęcie biopolityki do tych proponowanych przez Negriego i Agambena, to powiedziałbym, że nie tyle je zapośrednicza, ile jest wobec nich zewnętrzne. Oczywiście każdy z nas zaczyna tam, gdzie swoją pracę przerwał Foucault, i pragnie znaleźć odpowiedź na postawione przez niego pytanie o naturę i znaczenie biopolityki: czy mamy do czynienia ze zjawiskiem zasadniczo pozytywnym - innowacyjnym i pożytecznym, czy może raczej z odwrotem ku śmierci. Abstrahując od kwestii języka, jakim się posługujemy, i przyjętych na wstępie założeń, różni nas właśnie udzielana na to pytanie odpowiedź. Agamben w ahistoryczny, zadłużony u Martina Heideggera, Carla Schmitta i Waltera Benjamina sposób wydobywa tragiczną tonację biopolityki, Negri natomiast podkreśla witalność dynamiki, z jaką biopolityka się rozwija, nawiązując w tym do Spinozy, Karola Marksa i Gilles’a Deleuze’a. Negri widzi w niej szansę na wskrzeszenie w samym sercu Imperium, o którym pisze w swoich pracach $^{2}$, potencjału rewolucyjnego, zatem polemizując z pismami Foucaulta, akcentuje w biopolityce moment oporu wobec władzy. Ja natomiast staram się nie popadać w skrajności, lecz pchnąć dyskusję na nowe tory dzięki proponowanemu przeze mnie kluczowi interpretacyjnemu, który nie zapoznaje antynomiczności obydwu tych perspektyw, ale pozwala odczytać je wspólnie. Tym kluczem jest oczywiście paradygmat immunizacji, chroniący mnie przed porzuceniem historycznego wymiaru problemu, jak to czyni Agamben, i przed podporządkowaniem perspektywy filozoficznej polityce, co przydarza się Negriemu.

Timothy Campbell: To właśnie temu paradygmatowi poświęciłeś swoje ostatnie prace. W trylogii, na którą składają się Communitas, Immunitas i Bios, odczytujesz współczesne kategorie polityczne, prawne i estetyczne jako próbę uodpornienia ciała społecznego na niebezpieczeństwa wspólnotowego munus. Czy mógłbyś bardziej szczegółowo opisać cechy communitas i jej związki z nową formułą bios wykraczającą poza paradygmat immunizacji?

Roberto Esposito: W języku biomedycznym odporność to zdolność do obrony przed chorobą lub uwolnienia się od niej, a w żargonie prawniczym - immunitet albo zabezpieczenie, rozumiane jako nietykalność, jaką uodporniona osoba zyskuje wobec zobowiązań narzucanych przez prawo zwyczajowe. W obydwu zatem przypadkach odporność (immunity) lub uodpornienie (immunization) oznaczają ochronę przed ryzykiem, na które narażona jest cała wspólnota. Już tutaj widać będącą fundamentem moich prac opozycję wspólnoty (community) i odporności (immunity). Bez zagłębiania się w zawiłości etymologiczne, powiedzmy tylko, że odporność (łac. immunitas) jest odwrotnością wspólnoty (łac. communitas). Obydwa terminy mają ten

Zob.: M. Hardt, A. Negri, Imperium, przeł. S. Ślusarski, A. Kołbaniuk, Warszawa 2005, Z Wagq oraz ciż, Multitude. War and the Democracy in the Age of Empire, New York 2004. 
sam rdzeń i wywodzą się ze słowa munus, które po łacinie oznacza „dar”, „urząd” albo „obowiązek”, z tym że jeden z nich - communitas - ma konotacje pozytywne, podczas gdy drugi - immunitas - negatywne. Prawo daru i troski o innych obligowało bowiem członków wspólnoty do wzajemnego obdarowywania się, natomiast odporność oznacza zwolnienie z takiego obowiązku lub naruszenie go. $\mathrm{Z}$ tej perspektywy uodporniony jest ten, kto nie podlega nałożonemu na pozostałych - a prowadzącemu do pomniejszenia stanu posiadania i osłabienia pozycji obdarowującego - obowiązkowi obdarowywania.

Wysuwam w tym miejscu dwie zasadnicze tezy. Po pierwsze, termin immunizacja, rozumiany jako żądanie ochrony lub zwolnienia z obowiązku, nie ogranicza się już dziś do pierwotnych dziedzin medycyny i prawa, lecz obejmuje całość doświadczenia współczesności, zarówno rzeczywistego, jak i symbolicznego. W Immunitas starałem się prześledzić jego obecność nie tylko w medycynie i prawie, ale także w teologii, antropologii czy polityce. Należy zaznaczyć przy tym, że zainteresowanie tematyką odporności nie jest specyfiką naszych czasów - wszystkie społeczności musiały stawić czoła zagrożeniom ze strony środowiska naturalnego i innych ludzi, aby zagwarantować sobie przetrwanie. Mniejsza była natomiast świadomość grożącego ryzyka, a co za tym idzie - wiedza o sposobach radzenia sobie z tymi zagrożeniami. Pod tym względem mamy niewątpliwie przewagę.

Po drugie, konieczna dla ochrony życia odporność po przekroczeniu pewnego progu zamienia się w negację życia. Dlatego właśnie Immunitas nosi podtytuł „ochrona i negacja życia”, który równie dobrze mógłby brzmieć „ochrona jest negacją życia”, co oznacza, że w którymś momencie nakłada ona na życie pewną formę pancerza, pod którym nie ma już miejsca na wolność ani na poczucie jednostkowego i wspólnotowego istnienia. Innymi słowy, jesteśmy wówczas wyłączeni z obiegu społecznego, tych przejawów istnienia poza samym sobą, który nazywam wspólnotą: skierowanego w swej istocie poza siebie charakteru egzystencji. Sprzeczność polega więc na tym, że to, co chroni jednostkę i ciało polityczne, równocześnie uniemożliwia im rozwój, a na pewnym etapie może zacząć je niszczyć. Mówiąc językiem Benjamina, przedawkowanie immunizacji w celu przetrwania wymaga złożenia ofiary z życia ujmowanego jakościowo, co sprowadza je do wymiaru biologicznego.

Antynomia ochrony i negacji życia kryje się już w medycznej procedurze immunizacji. Szczepiąc pacjenta, wprowadzamy do jego organizmu tę samą substancję, która odpowiada za wystąpienie choroby, tyle że w ograniczonej dawce. Substancje chorobotwórcze mogą więc zarówno szkodzić, jak i służyć nabyciu odporności, a dla ochrony życia trzeba posmakować tego, co śmiercionośne. Jak pokazał Jacques Derrida ${ }^{4}$, grec-

Zob.: R. Esposito, Immunitas. Protezione e negazione della vita, Torino 2002. Warto odnotować, że ta paradoksalna semantyka ukryta w podtytule Immunitas jest w języku włoskim dodatkowo uwypuklona: $e$ w znaczeniu spójnika „i” oraz è w przypadku trzeciej osoby czasownika „być” brzmią właściwie identycznie. Taka sama sytuacja zachodzi jeszcze - jak się zdaje - tylko w języku francuskim: et oraz est.

4 Zob.: J. Derrida, Farmakon, przeł. K. Matuszewski, [w:] tegoż, Pismo filozofii, wybór i przedm. B. Banasiak, Kraków 1993. 
ki termin pharmakon zawiera w sobie to podwójne znaczenie „leku” i „trucizny” albo leczenia poprzez zatrucie. Współczesne procedury immunizacji doprowadziły jednak tę antynomię do ekstremum - coraz więcej leków przybiera dziś postać śmiertelnej trucizny.

Timothy Campbell: W trakcie czytania Bios odniosłem wrażenie, że inaczej niż w Immunitas ujmujesz tu paradygmat immunizacji. Nie jest on już dla Ciebie metodą dekonstrukcji politycznych i prawnych kategorii nowoczesności, lecz raczej przeszkodą w nakreśleniu projektu biopolityki afirmatywnej. Ciekawi mnie, czy zgadzasz się z tą obserwacją, a jeśli tak, to co wywołało tę zmianę? Czy to wydarzenia ostatnich lat sygnalizują, że w centrum globalnej polis rodzi się nowa formuła życia, bios?

Roberto Esposito: Nie powiedziałbym, że moje podejście do kategorii immunizacji uległo zmianie. Zmieniły się natomiast częściowo ramy teoretyczne, w jakie ją wpisuję. Faktycznie do czasów Communitas miałem na celu pewnego rodzaju dekonstrukcję politycznego języka nowoczesności, co widać szczególnie w mojej pracy dotyczącej zjawiska niepolityczności ${ }^{5}$. Stopniowo zaczęła nakładać się na to inna perspektywa, bardziej konstruktywna i zmierzająca w kierunku zarysowanym przez Deleuze'a, według którego wyróżnikiem filozofii powinno być formułowanie koncepcji, będących w stanie nadążyć za angażującymi i zmieniającymi nas wydarzeniami ${ }^{6}$. Drugim punktem odniesienia w ciągu ostatnich kilku lat stała się dla mnie ścieżka analityczna biegnąca od genealogii Fryderyka Nietzschego aż do ontologii aktualności Foucaulta. Obydwaj ci autorzy, a zwłaszcza pojęcie ontologii, jakkolwiek by je rozumieć, odsyłają nas oczywiście do Heideggera, choć z istotną różnicą, którą starałem się naświetlić w Bios oraz w niedawnym tekście poświęconym posthumanistycznej idei natury ludz$\mathrm{kiej}^{7}$. Chodzi mi o centralne miejsce, jakie zajmuje w moich pracach kategoria życia, która u Heideggera była ledwie marginalna. Na początku swojej kariery we Fryburgu określił on życie mianem "faktycznego" ${ }^{8}$, by następnie wprowadzić pojęcie „egzystencji”, programowo usuwane w tym czasie z języka biologii. Jednak mimo uwagi, jaką Heidegger przywiązywał do codziennego wymiaru egzystencji, nigdy nie ujmował w kategoriach biologicznych tematyki ciała.

Zob.: R. Esposito, Categorie dell'impolitico, Bologna 1999 lub dostępny w języku angielskim fragment: tenże, Preface to Categories of the Impolitical, trans. by C. Parsley, „Diacritics” 2009, Vol. 39, nr 2, s. 99 -115 .

6 Zob.: G. Deleuze, F. Guattari, Co to jest filozofia?, przeł. P. Pieniążek, Gdańsk 2000, Minerwa. Biblioteka filozofii i historii filozofii.

7 R. Esposito, „Il post-umano”, [w:] Post-umano. Relazioni tra uomo e tecnologia nella società delle reti, a cura di M. Pireddu, A. Tursi, Milano 2006.

8 Wydaje się, że Roberto Esposito może mieć tu na myśli przede wszystkim dwie pozycje z bogatej bibliografii Martina Heideggera: M. Heidegger, Ontologia (hermeneutyka faktyczności), przel. M. Bonecki, J. Duraj, Toruń 2007, Klasyka Filozofii Niemieckiej oraz tenże, Fenomenologia życia religijnego, przeł. G. Sowiński, Kraków 2002, Filozofia i Religia. Za konsultację przy tłumaczeniu tego terminu podziękowania należą się Januszowi Mizerze. 
Podkreślał to w swoich pracach Maurice Merleau-Ponty ${ }^{9}$, który zaciekawił mnie powiązaniem tematyki ciała z kategorią „mięsa” $\left(\text { fles }^{10}\right)^{10}$, dzięki czemu zdystansował się od klasycznej Husserlowskiej fenomenologii. Wydaje mi się - o czym pisałem w Bios - że powracający u Merleau-Ponty'ego motyw chiazmu ciała i mięsa można wykorzystać do pozytywnego odczytania biopolityki. Aby w ogóle można było myśleć o czymś takim jak polityka życia, konieczne jest bowiem zerwanie wytworzonego w epoce nowoczesnej związku między biopolityką a immunizacją. W Bios, zwłaszcza w częściach poświęconych analizie nazizmu i jego źródeł, starałem się pokazać, że immunitarna koncepcja biopolityki, jeśli tylko ją zradykalizować, wyradza się nieuchronnie w tanatopolitykę, czyli politykę śmierci. Merleau-Ponty jest dla mnie tak cenny, ponieważ uzmysławia, że to właśnie biopolityka ograniczona do procedury immunizacji, albo lepiej - autoimmunizacji, zrodziła ideę, którą wcieliła później w życie nazistowska biokracja: ciała, na poziomie którego wszystko się zaczyna i wszystko kończy (organicystyczna metafora ciała politycznego była przy tym zawsze mocno konserwatywna, a od czasów faszystowskiego korporacjonizmu dodatkowo reakcyjna). Merleau-Ponty dekonstruuje to zamknięte w sobie pojęcie ciała, aby umożliwić otwarcie go na to, co zewnętrzne, oraz na różnicę, która tkwi przecież w nim samym. I tu właśnie przydaje się kategoria mięsa, obecna już w tradycji chrześcijańskiej, a później w fenomenologii. Jeśli spróbować odczytać ją przez pryzmat dwudziestowiecznej awangardy, zwłaszcza tej w wydaniu Francisa Bacona i Davida Cronenberga, widać jej wyraźny potencjał subwersywny, bowiem mięso to ciało, które - wbrew temu, do czego według Emmanuela Lévinasa zmierzał nazizm - nie jest w pełni z sobą zgodne, nie tworzy od samego początku organicznej jedności, wreszcie - nie wieńczy go głowa (jest zatem, mówiąc językiem Georges’a Bataille’a, acefaliczne). Zamiast tego, mięso to nieforemna, różnorodna wielość, która może stanowić inspirację dla projektu biopolityki afirmatywnej i jego punkt wyjścia.

Timothy Campbell: Nieco odmiennie o tej kwestii wypowiadał się przed śmiercią Derrida. W wywiadach poświęconych wydarzeniom z 11 września $^{11}$, a także w reda-

9 Jak słusznie stwierdza Marek Drwięga w swoim studium o roli cielesności w filozofii Merleau-Ponty’ego, nie sposób w przypadku tego filozofa odesłać czytelnika do jednej tylko pozycji książkowej poświęconej tematyce ciała; być może za najważniejszą - ze względu na kategorię mięsa - należałoby uznać: M. Merleau-Ponty, Widzialne i niewidzialne, przeł. M. Kowalska, Warszawa 1996. Godny polecenia jest zatem rozdział pt. Semantyczna teoria ciata, czyli Merleau-Ponty'ego rozważania o cielesności w: M. Drwięga, Ciato cztowieka. Studium z antropologii filozoficznej, Kraków 2002, s. 163-227.

10 W języku polskim trudno o dobry odpowiednik wyraźnego w języku włoskim, francuskim, niemieckim czy angielskim rozróżnienia il corpo i la carne, le corps i la chair, Körper i Leib, body i flesh. Aby zachować znaczenie wypływające z zestawienia tych terminów, angielskie flesh zostało oddane jako „mięso”. Rozwiązanie to stosowano już zresztą w języku polskim w kontekście filozofii Merleau-Ponty'ego.

11 Zob.: G. Borradori, Dekonstruujac terroryzm. Derrida, [w:] Filozofia z czasach terroru. Rozmowy z Jürgenem Habermasem i Jacques'em Derridą, przeprowadziła i komentarzem opatrzyła G. Borradori, przeł. A. Karalus, M. Kilanowski, B. Orlewski, wstęp i red. A. Szahaj, Warszawa 2008, Reflektor. 
gowanym wespół z Giannim Vattimo zbiorem tekstów zatytułowanym Religia ${ }^{12}$ utożsamił on proces autoimmunizacji z następstwami traumy - z przeświadczeniem, że nadciąga katastrofa. Twoja interpretacja jest $\mathrm{z}$ kolei mocno zakorzeniona w koncepcji biopolityki, jaką można wyczytać z pism Nietzschego i Foucaulta. Co zatem rozumiesz pod pojęciem „doświadczenia wydarzenia”, którym Derrida próbował opisać 9/11 jako symptom ogólnoświatowego kryzysu autoimmunizacji?

Roberto Esposito: Zacznę może od ogólniejszej uwagi. To, jak wielu wybitnych współczesnych myślicieli - Derrida, Sloterdijk, Heller, Haraway - niezależnie od siebie i różnymi ścieżkami dotarło do rozważań nad kategorią immunizacji, najlepiej świadczy o tym, jak wielkie ma ona dla nas znaczenie. Filozofia, która chce dotrzymać kroku światu, nie może pozostać na nią obojętna. Widać to zresztą nie od dziś - paradygmat immunizacji odgrywał kluczową rolę już u Nietzschego, by później powrócić w antropologii filozoficznej Helmutha Plessnera i Arnolda Gehlena, czy w analizie prawa jako systemu immunitarnego dokonanej przez Niklasa Luhmanna ${ }^{13}$. Problem zatem dotyczy faktycznie nie tego, czy zajmujemy się immunizacją, ale sposobu, w jaki ją rozumiemy i poddajemy analizie. Sloterdijk ${ }^{14}$ i Haraway ${ }^{15}$ są tu przykładowo o wiele bardziej optymistycznie nastawieni niż Derrida, który począwszy od eseju o religii, mówi nie tyle o immunizacji, ile o autoimmunizacji, nawiązując w tym oczywiście do pojęcia chorób autoimmunologicznych. Derrida ma rację, opisując rzeczywistość polityczną po 11 września w kategoriach destrukcji i autodestrukcji. Również odnoszę wrażenie, że wojna w Iraku podwójnie wiąże się z paradygmatem immunizacji i jest rozpaczliwą, niekontrolowaną próbą uodpornienia się, która skutkuje „kryzysem immunitarnym” rozumianym analogicznie do „kryzysu ofiarniczego” René Girarda ${ }^{16}$. Zapoczątkowany atakami z 11 września i kontynuowany obecnie ${ }^{17} \mathrm{w}$ Iraku konflikt jest efektem dwóch wrogich sobie obsesji immunizacji. Jedna stała się udziałem islamskiego fundamentalizmu, walczącego z zepsutym Zachodem o zachowanie czystości, druga zaś przynależy tej części zachodniej cywilizacji, która nie chce dzielić się nadwyżką posiadanych dóbr z głodującą resztą świata, by samej nie popaść w ubóstwo. Nie chcę przez to powiedzieć, że odpowiedzialność rozkłada się tu po równo ani że można usprawiedliwić terroryzm.

12 Zob.: J. Derrida, Wiara i wiedza. Dwa źródta „religii” w obrębie samego rozumu, [w:] J. Derrida, G. Vattimo, Religia. Seminarium na Capri prowadzone przez Jacquesa Derride i Gianniego Vattimo, w którym udziat wzięli Maurizio Ferraris et al., przeł. M. Kowalska i in., Warszawa 1999.

13 Zob.: N. Luhmann, Systemy spoteczne. Zarys ogólnej teorii, przeł. M. Kaczmarczyk, Kraków 2007, Wspótczesne Teorie Socjologiczne, 1.

14 Zob.: P. Sloterdijk, Sphären. I - Blasen, Mikrosphärologie, Frankfurt am Main 1998, tenże, Sphären. II - Globen, Makrosphärologie, Frankfurt am Main 1999; tenże, Sphären. III - Schäume, Plurale Sphärologie, Frankfurt am Main 2001.

15 Trudno przywołać w tym kontekście jedną zaledwie pozycję Donny J. Haraway, nie sposób jednak pominąc jej eseju The Biopolitics of Postmodern Bodies. Constitutions of Self in Immune System Discourse w: Feminist Theory and the Body. A Reader, ed. J. Price, M. Shildrick, New York 1999.

16 Zob. przede wszystkim: R. Girard, Sacrum i przemoc, przeł. M. i J. Plecińscy, Poznań 1993, Dzieje Gnozy, t. 5 oraz tenże, Koziot ofiarny, przeł. M. Goszczyńska, Łódź 1991, Cztowiek i Jego Cywilizacja.

17 Rozmowa przedstawiana tu w formie wywiadu miała miejsce w sierpniu $2005 \mathrm{r}$. 
Twierdzę jedynie, że z perspektywy systemowej splot tych obsesji wprawia cały świat w konwulsje noszące wszelkie znamiona najbardziej niszczycielskiej z chorób autoimmunologicznych: nadmiernie broniący się organizm ulega pokusie pozbycia się wszelkich ciał obcych, co ostatecznie staje się dla niego samego śmiertelnym zagrożeniem. Zawalenie się wież WTC było więc z tej perspektywy symboliczną destrukcją systemu odpornościowego świata.

W tym punkcie całkowicie podzielam intuicje Derridy, jednak pewne ważne problemy związane z powstawaniem odporności wydają się u niego nie w pełni przemyślane, skoro immunizacji nie wiąże ani ze wspólnotą, którą zastępuje kategorią przyjaź$\mathrm{ni}^{18}$, ani z tematyką biopolityczną. To wyizolowanie nie pozwala Derridzie uchwycić dialektyki immunizacji, czyli dostrzec, że życie - pojedyncze i zbiorowe - bez aparatury odpornościowej nie przetrwa. W efekcie brakuje w jego pracach refleksji nad tym, jak odtworzyć zniszczony dziś paradygmat immunizacji, tak istotny dla całego nowoczesnego świata. Dla mnie z kolei immunizacja jest nierozerwalnie, choć w negatywny sposób, związana z pojęciem wspólnoty, co umożliwia komunitarystyczną interpretację tego odpornościowego dispositif ${ }^{9}$, nad którym pracę podjąłem w końcowej części Immunitas. Tę drogę wskazują zresztą podejmowane aktualnie badania w dziedzinie medycyny, które pokazują, że system odpornościowy - to, co definiujemy jako tolerancję immunologiczną - jest warunkiem umożliwiającym przeszczepianie organów. Oczywiście niełatwo przełożyć mające negatywny wydźwięk pojęcie „wspólnej odporności” na język etyki i polityki, ale uważam, że należy podjąć to wyzwanie. Mówiąc jeszcze inaczej, Derrida widział w autoimmunizacji siłę witalną, która zwraca się przeciwko sobie i może sama siebie unieważnić, podczas gdy dziś musimy skupić się nie tylko na autodestrukcyjnym wymiarze tej dialektyki, ale także na jej twórczym, możliwym do spożytkowania potencjale.

Timothy Campbell: W Bios zajmujesz się szerzej związkami paradygmatu immunizacji z globalizacją i wyraźnie łączysz go z procesami modernizacyjnymi, które zastąpiły wspólnotowe formy organizacji modelem indywidualistycznym. Czy w dzisiejszym kryzysie autoimmunizacji, o którym mówisz, znajdujesz coś, co świadczyłoby o zerwaniu z tym, co nowoczesne?

Roberto Esposito: Gdybyśmy mieli wyznaczyć symboliczny punkt wyjścia rozważań o nowoczesnym procesie immunizacji, znaleźlibyśmy go zapewne u Hobbesa. To wtedy problem zachowania życia znalazł się w centrum teorii i praktyki politycznej. W sposób typowy dla negatywnej dialektyki immunizacji jednostki przekazują tu swoje przy-

18 Por.: J. Derrida, Politiques de l'amitié, Paris 1994 oraz tenże, Polityka przyjaźni, przeł. T. Zarębski, „Odra” 2001, nr 7-8, s. 46-52.

19 Termin dispositif wywodzi się oczywiście od Michela Foucaulta - więcej na ten temat zob. np.: M. Foucault, Le jeu de Michel Foucault (Rozmowa z redakcja czasopisma „Ornicar?”), „Ornicar? Bulletin Périodique du champ freudien” 1977, nr 10, s. 62-93, gdzie francuski filozof określa dispositif jako odpowiednik pojęcia épistème na polu społecznym. Nie od rzeczy będzie wspomnieć w tym miejscu również: G. Agamben, Czym jest urządzenie?, przeł. J. Majmurek, [w:] Agamben. Przewodnik Krytyki Politycznej, Warszawa 2010, s. 82-100, Przewodniki Krytyki Politycznej, t. 18. 
rodzone uprawnienia suwerenowi, poświęcając je dla ochrony przed kryjącym się we wspólnocie ryzykiem utraty życia. W zasadzie wszystkie kategorie polityczne wykorzystywane przez Hobbesa i jego następców - suwerenność, wolność, własność - są tylko sposobem przełożenia kwestii odporności na język filozofii prawa. Wydaje się więc, że to nie nowoczesność zrodziła problem immunizacji, lecz immunizacja doprowadziła do powstania nowoczesności, czyli kompleksu idei mających na celu ochronę życia. Nowoczesność bowiem to nic innego, jak język umożliwiający skuteczniejszą odpowiedź na problem samozachowania, tkwiący u samych podstaw życia. Potrzeba ochrony, której przejawem była chociażby umowa społeczna, narodziła się i nabrała znaczenia w momencie, gdy dotychczasowe mechanizmy obronne, takie jak oparcie w transcendencji, zaczęły słabnąć. Brak tej naturalnej tarczy ochronnej wymagał dalszego dispositif, tym razem sztucznego, który zagwarantowałby ludzkiemu życiu ochronę, np. przed ryzykiem wojny domowej lub najazdu innego państwa. Człowiek nowoczesny, innymi słowy, potrzebuje aparatu immunizacji dla ochrony życia, które wraz z nastaniem procesu sekularyzacji zostało uzewnętrznione i pozostawione samemu sobie. Oczywiście, jak wszystko w dialektyce immunizacji, miało to swoją cenę, którą było w tym przypadku odwrócenie znaczenia nowoczesnych kategorii politycznych, na czele z pojęciem wolności.

Dzisiaj porzuciliśmy charakterystyczną dla wczesnej nowoczesności semantykę immunizacji. Podstawową zmianą, patrząc z perspektywy biopolitycznej, stało się odejście od zapośredniczenia związków polityki i ochrony życia przez paradygmat porządku, wyrażający się w pojęciach suwerenności, reprezentacji i uprawnień jednostkowych. Współcześnie polityka i życie nakładają się na siebie o wiele bardziej bezpośrednio. W efekcie mechanizmy immunizacji, które niegdyś pracowały dla zagwarantowania ładu, uciekają się do tworzenia coraz silniejszych i szerzej zakrojonych zabezpieczeń, przez co często nie chronią, lecz same stanowią zagrożenie. Przyczyną tego stanu rzeczy jest to, co powszechnie nazywa się globalizacją. Wraz ze wzrostem powiązań międzyludzkich, rozwojem kontaktów językowych czy wymiany idei i technologii rozszerza się jako przeciwwaga dla nich zjawisko immunizacji prewencyjnej. Jak podkreśla Derrida, pojawienie się nowych lokalnych enklaw ze skłonnością do etnofundamentalizmu można tłumaczyć właśnie próbą uodpornienia się na niesione przez globalizację zepsucie. Upadek wielkiego muru berlińskiego, symboliczny moment globalizacji, doprowadził do wzniesienia wielu mniejszych murów. To właśnie można określić mianem przejścia od immunizacji do autoimmunizacji, czyli takiej formy odporności, która niszcząc wroga, niszczy też siebie. Ta perspektywa otwiera pole do interpretacji zarówno nazistowskiej tanatopolityki, jak i wydarzeń związanych z atakami na WTC. Najnowsza i najstraszliwsza formuła autoimmunizacji może też jednak, jak już wspomniałem, urzeczywistnić scenariusz, o jakim nam się dotąd nie śniło.

Timothy Campbell: Gdy czytałem rozdział Bios poświęcony nazistowskiej tanatopolityce, uderzył mnie Twój opis eksterminacji Żydów w kategoriach „homeopatycznych”, które miałyby kryć się w logicznym i znaczeniowym tańcuchu tączącym zjawiska dege- 
neracji, regeneracji i ludobójstwa ${ }^{20}$. Wyszczególniasz tam ponadto trzy cechujące tanatopolitykę mechanizmy immunizacyjne: podwójne zamknięcie ciała, normatywizację życia oraz jego zapobiegawcze stłumienie ${ }^{21}$. Doceniam subtelność takiej interpretacji, ale mam pewne wątpliwości dotyczące wpisania zbrodni nazistowskich w horyzont współczesnej biopolityki. Czy nie uważasz, że pomijanie historycznej specyfiki obozów śmierci jest ryzykowne?

Roberto Esposito: Istotnie, ryzyko, o którym mówisz, istnieje, jednak do pewnego stopnia nie sposób go w analizach nazizmu uniknąć. Zawsze pojawia się choćby kwestia definicji czegoś takiego jak ludobójstwo, co nie mieści się w zwyczajowej terminologii etycznej i politycznej, a przez to wymyka się konceptualizacji. Mimo to uważam, że jeśli nie chcemy ciągle obracać się w kręgu tradycyjnych analiz albo, co gorsza, skazać się na milczenie lub amnezję, ryzyko takie należy podjąć. Pierwsze wskazówki, jak to zrobić, znajdziemy u Foucaulta i w pouczających fragmentach dzieł Lévinasa, a ostatnio także w pracach Agambena. Dla mnie osobiście cenny okazał się namysł nad całym cyklem ghenos, od narodzin aż do śmierci.

Starałem się odkryć, co dla nazistów oznaczała śmierć, zaczynając od wypaczonej przez nich koncepcji biopolityki, która była sednem całej praktyki nazizmu i nie mogła skończyć się niczym innym niż katastrofą. Jednak śmierć była dla uznających się za rasę wybraną nazistów czymś o wiele bardziej złożonym: w swoim pragnieniu nieśmiertelności obsesyjnie się jej bali, a jednocześnie za jej pomocą chcieli tę nieśmiertelność osiągnąć. Ten paradoks sprawił, że próba unicestwienia tego, co tak im zagrażało, poprzez akt eksterminacji innych zebrała później krwawe żniwo wśród nich samych. Na tym polega śmiercionośny charakter nazizmu, który ich biopolityka zakładała z pełną dosłownością. Chcąc za wszelką cenę ocalić życie niemieckich obywateli i ochronić ich przed skażeniem, naziści wydali ich wszystkich na śmierć, czego dopełnił ostatni rozkaz Adolfa Hitlera na barykadach ${ }^{22}$. Takie były konsekwencje nazistowskiej logiki, zakładającej, że życie, które ma ulec zniszczeniu, jest od początku życiem skazanym na śmierć, życiem przez tę śmierć wytwarzanym i zamieszkiwanym. Dlatego też ci, którzy zadawali śmierć, nie uważali się za zabójców, lecz kogoś w rodzaju bezstronnych sędziów, przywracających naturalne granice między życiem a śmiercią, naruszone przez łączenie ras. Wierzyli w swoim morderczym szale, że oddają jedynie życie we władanie śmierci, do której i tak zawsze jako martwo urodzone należało ${ }^{23}$.

Takie pojmowanie śmierci wpływało też na ambiwalentny stosunek nazizmu do faktu narodzin, które tyleż ich fascynowały, co napawały wstrętem. Narodziny były dla nazistów prowokacją domagającą się unicestwienia. Gisela Bock w książce Maternity and Gender Policies zwróciła uwagę na zasadniczą niespójność między wyznawaną przez nich ideologią natalistyczną a niszczeniem narodzonego życia w praktyce. Wiadomo,

20 R. Esposito, Bios. Biopolitics and Philosophy, trans. by T.Campbell, Minneapolis 2008, s. 137.

21 Tamże, s. 127-145.

22 Chodzi oczywiście o depeszę Hitlera wysłaną przed ostateczną klęską III Rzeszy z berlińskiego bunkra, nakazującą narodowi niemieckiemu zbiorowe samobójstwo.

23 Tu i dalej por.: rozdział pt. Thanatopolitics (The Cycle of Genos) w: R. Esposito, Bios..., s. 110-145. 
że celem nazistów było zwiększenie wskaźnika urodzeń wśród Niemców, czego wyrazem był całkowity zakaz aborcji i wsparcie finansowe udzielane rodzinom posiadającym więcej niż dwójkę dzieci. Ciągłość urodzeń wśród obywateli o identycznej krwi była też rodzajem spoiwa jednoczącego pokolenia Niemców. Jeśli bowiem faktycznie Państwo jest ciałem zamieszkujących go ludzi - w co naziści mocno wierzyli - i jeśli ci mieszkańcy zjednoczeni są w ciele przywódcy, to polityka służy po prostu podtrzymaniu narodzin jako jedynej żywej siły napędzającej historię. Jednocześnie wartościowane politycznie narodziny stają się linią dokonującą podziału w obrębie życia, wyróżniając szereg porządków podległości: panów i niewolników, ludzi i zwierząt, żywych i martwych. Są tym samym przedmiotem suwerennej decyzji, z góry różnicującej je aksjologicznie. Ambiwalencja faktu narodzin w nazizmie polega zatem na tym, że z jednej strony są one początkiem doskonałego rasowo życia, a z drugiej mogą pozbawiać osoby skazane na śmierć statusu istot żywych, zgodnie z założeniem, że zasługują one na śmierć, ponieważ nigdy się w pełni nie narodziły. Utożsamiona z narodem niemieckim kategoria narodzin podziela tutaj los życia i również staje się instrumentem biopolityki, którą podważyć może tylko zbiorowa śmierć.

\section{Przetożyt Piotr Sawczyński Przypisy opracowat Mateusz Burzyk}

\section{BIBLIOGRAFIA}

Agamben G., Czym jest urzadzenie?, przeł. J. Majmurek, [w:] Agamben. Przewodnik Krytyki Politycznej, Warszawa 2010, s. 82-100, Przewodniki Krytyki Politycznej, t. 18.

Borradori G., Dekonstruujac terroryzm. Derrida, [w:] Filozofia w czasach terroru. Rozmowy z Jürgenem Habermasem i Jacques'em Derrida, przeprowadziła i komentarzem opatrzyła G. Borradori, przeł. A. Karalus, M. Kilanowski, B. Orlewski, wstęp i red. A. Szahaj, Warszawa 2008, Reflektor.

Deleuze G., Guattari F., Co to jest filozofia?, przel. P. Pieniążek, Gdańsk 2000, Minerwa. Biblioteka filozofii i historii filozofii.

Derrida J., Farmakon, przeł. K. Matuszewski, [w:] tenże, Pismo filozofii, wybór i przedm. B. Banasiak, Kraków 1993.

Derrida J., Politiques de l'amitié, Paris 1994.

Derrida J., Polityka przyjaźni, przeł. T. Zarębski, „Odra” 2001, nr 7-8.

DerridaJ., Wiarai wiedza. Dwaźródta ,religii" wobrębiesamego rozumu, [w:]J.Derrida, G. Vattimo, Religia. Seminarium na Capri prowadzone przez Jacquesa Derridę i Gianniego Vattimo, w którym udziat wzięli Maurizio Ferraris et al., przeł. M. Kowalska i in., Warszawa 1999.

Drwięga M., Ciato cztowieka. Studium z antropologii filozoficznej, Kraków 2002.

Esposito R., Bios. Biopolitics and Philosophy, trans. by T.Campbell, Minneapolis 2008.

Esposito R., Categorie dellimpolitico, Bologna 1999.

Esposito R., „Il post-umano”, [w:] Post-umano. Relazioni tra uomo e tecnologia nella società delle reti, a cura di M. Pireddu, A. Tursi, Milano 2006. 
Esposito R., Immunitas. Protezione e negazione della vita, Torino 2002.

Esposito R., Preface to Categories of the Impolitical, trans. by C. Parsley, „Diacritics” 2009, Vol. 39 , nr 2, [online] http://dx.doi.org/10.1353/dia.2009.0010.

Esposito R., Campbell T., Interview, trans. by A. Paparcone, „Diacritics” 2006, Vol. 36, nr 2.

Foucault M., Le jeu de Michel Foucault (Rozmowa z redakcja czasopisma „Ornicar?”), „Ornicar? Bulletin Périodique du champ freudien" 1977, nr 10.

Girard R., Koziot ofiarny, przeł. M. Goszczyńska, Łódź 1991, Cztowiek i Jego Cywilizacja.

Girard R., Sacrum i przemoc, przeł. M. i J. Plecińscy, Poznań 1993, Dzieje Gnozy, t. 5.

Haraway D.J., The Biopolitics of Postmodern Bodies. Constitutions of Self in Immune System Discourse, [w:] Feminist Theory and the Body. A Reader, eds. J. Price, M. Shildrick, New York 1999.

Hardt M., Negri A., Imperium, przeł. S. Ślusarski, A. Kołbaniuk, Warszawa 2005, Z Waga. Hardt M., Negri A., Multitude. War and the Democracy in the Age of Empire, New York 2004.

Heidegger M., Fenomenologia życia religijnego, przeł. G. Sowiński, Kraków 2002, Filozofia i Religia.

Heidegger M., Ontologia (hermeneutyka faktyczności), przeł. M. Bonecki, J. Duraj, Toruń 2007, Klasyka Filozofii Niemieckiej.

Luhmann N., Systemy spoteczne. Zarys ogólnej teorii, przeł. M. Kaczmarczyk, Kraków 2007, Wspótczesne Teorie Socjologiczne, 1.

Merleau-Ponty M., Widzialne i niewidzialne, przeł. M. Kowalska, Warszawa 1996.

Sloterdijk P., Sphären. I - Blasen, Mikrosphärologie, Frankfurt am Main 1998.

Sloterdijk P., Sphären. II - Globen, Makrosphärologie, Frankfurt am Main 1999.

Sloterdijk P., Sphären. III - Schäume, Plurale Sphärologie, Frankfurt am Main 2001.

Roberto ESPOSITO - profesor filozofii, wicedyrektor Istituto Italiano di Scienze Umane di Napoli (Włochy) i koordynator programu studiów doktoranckich w zakresie filozofii; współpracownik Collège International de Philosophie; założyciel the European Political Lexicon Research Centre oraz the International Centre for a European Legal and Political Lexicon; współpracownik i konsultant włoskich wydawnictw (Einaudi, Il Mulino, Franco Angeli, Bibliopolis) w zakresie filozofii politycznej i współczesnej; przede wszystkim jednak autor rozlicznych publikacji, wśród których najważniejsze to: Communitas, Immunitas, Bios, Terza Persona, Pensiero vivente - książki szeroko dyskutowane i tłumaczone na kilka języków. 